\title{
On a Difference in the Antifungal Activity of Tridemorph and Its Formulated Product Calixin
}

\author{
A. Kerkenaar and A. KaArs Sijpesteijn \\ Institute for Organic ('hemistry TNO (Organization for Applied Scientific Research). Croesestraat 79, \\ 3522 AD, P.O. Box 5009, 3502 JA, Utrecht, The Netherlands \\ Received February 28, 1979; accepted June 5, 1979
}

\begin{abstract}
The antifungal effects of tridemorph and its formulated product Calixin were compared in vitro, on Ustilago maydis, Saccharomyces cerevisiae. Torulopsis candida. Botrytis allii, and Cladosporium cucumerinum. MIC values for both products were about the same. In liquid media the products were somewhat more effective than on solid media. $T$. candida proved sensitive only at $\mathrm{pH} 5$, but the other organisms were as sensitive at $\mathrm{pH} 7$ as at $\mathrm{pH}$ 5. Whereas tridemorph even at high concentrations did not affect oxygen consumption of these organisms, Calixin at concentrations slightly above the MIC values appeared to inhibit respiration. This effect of Calixin could be explained by the presence of Nekanil LN in the formulation. This compound inhibited both growth and respiration of the organisms at high concentrations; however, in the simultaneous presence of tridemorph a synergistic effect on oxygen consumption was observed.
\end{abstract}

\section{INTRODUCTION}

The fungicide tridemorph $(2,6$-dimethyl- $N$-tridecylmorpholine) is effective against powdery mildews (1) and other fungi; it has both systemic and eradicant properties (2). Different modes of action have been proposed for this compound. Bergmann et al. (3, 4), Müller and Schewe $(5,6)$, and Rapoport (7) argued that the primary effect of tridemorph on Torulopsis candida should be in the respiratory chain. In contrast, Garg and Mehrotra (8) reported that Calixin inhibited growth of Fusarium solani f.sp. pisi without significant inhibitory effect on the rate of respiration. Fisher (9) reported inhibition of protein synthesis in protoplasts of Neurospora crassa and Botrytis fabae, and Polter and Casparson (11) interference with lipid biosynthesis in Botrytis cinerea. On the other hand Kaars Sijpesteijn (10) had made the suggestion that tridemorph might well interfere with the cell membrane function.

The various authors used different organisms and, moreover, in certain instances it is not clear whether they used tridemorph or the formulated product Calixin. To obtain more clarity we compared for various yeasts and filamentous fungi the effect of tridemorph and Calixin on growth and respiration. In adddition, several experiments were carried out with Nekanil LN, a product used to formulate tridemorph.

\section{MATFRIAI, AND MFTHODS}

Organisms. Ustilago maydis (DC) Corda ATCC 14862, Saccharomyces cerevisiae (own isolate), Torulopsis candida (Saito) Lodder CBS 940, Botrytis allii Munn CBS 103.23, and Cladosporium cucumerinum (obtained from Dr. M. H. van Raalte, Wageningen, The Netherlands) were used throughout this study. Stock cultures were maintained on malt extract (Oxoid $30 \mathrm{~g} /$ /iter) agar slants at $4^{\circ} \mathrm{C}$.

Chemicals. Pure tridemorph (2,6dimethyl - $N$ - tridecylmorpholine, double distilled), Calixin (a 75\% tridemorph formulation), and Nekanil LN (condensation product of octylphenol with 5 to $6 \mathrm{~mol}$ ethyleneoxide, which is used to formulate Calixin) were generously supplied by BASF Aktiengesellschaft (Ludwigshafen, BRD).

The purity of pure tridemorph was above 99.9\% and of tridemorph in Calixin about 98\%. Besides Nekanil LN no other inert ingredients were present in the Calixin for- 
mulation. The Calixin formulation had not been changed during the period of 19741977. (According to information kindly obtained from BASF Aktiengesellschaft).

Antifungal activity of compounds. Antifungal activity was determined in growth tests on solid media or in nutrient solutions. Toxicants were added from concentrated graded solutions in acetone. The final acetone concentration did not exceed $0.6 \%$. The concentration range of each toxicant was $0,1,3,10,30,100,300$, and 1000 $\mu \mathrm{g} / \mathrm{ml}$. Concentrations of Calixin were always corrected for tridemorph content.

The synthetic media used were: Coursen and Sisler agar (12) for $U$. maydis and $T$. candida, Wickerham, modified by Roman agar (13) for $S$. cerevisiae, and glucose mineral salts agar (14) for $B$. allii and $C$. cucumerinum. As liquid media solutions of the same composition were used. Unless otherwise indicated the $\mathrm{pH}$ value was always adjusted to about 7 after autoclaving. To obtain $\mathrm{pH} 5$ the ratio between $\mathrm{K}_{2} \mathrm{HPO}_{4}$ and $\mathrm{KH}_{2} \mathrm{PO}_{4}$ was changed.

Cells of $U$. maydis, $S$. cerevisiae, and $T$. candida were streaked onto the agar from a thin suspension in saline. B. allii and $C$. cucumerinum were added as conidia $(2 \times$ $10^{4}$ conidia/ml medium) to molten agar $\left(50^{\circ} \mathrm{C}\right)$ before pouring the plates. Similar amounts were used to inoculate liquid media.

Minimal inhibitory concentrations (MIC; no macroscopically visible growth) were determined after different incubation periods.
Antifungal effects of toxicants in shake cultures were determined by measuring the increase in optical density (OD; $535 \mathrm{~nm}$ ) of $U$. maydis, $S$. cerevisiae, and $T$. candida or the increase in dry weight of $B$. allii and $C$. cucumerinum.

Respiration measurements. The effect of the toxicants on oxygen consumption by 24-hr-old mycelial pellets of $B$. allii and $C$. cucumerinum or 16-hr-old cells of $U$. maydis, $S$. cerevisiae, and $T$. candida was determined in $0.03 M$ phosphate buffer, $\mathrm{pH}$ 7.0 (for $T$. candida, $\mathrm{pH} 5$ ), by conventional Warburg technique. Glucose and toxicant were tipped in from the side arms at zero time.

\section{RESULTS}

\section{Growth Inhibition by Tridemorph and}

Calixin of $U$. maydis, $S$. cerevisiae, $T$. candida, $B$. allii, and $C$. cucumerinum

The growth inhibiting effect of tridemorph with regard to five organisms was quite similar to that of the formulated product Calixin (Table 1). A strong influence of the $\mathrm{pH}$ value was only noticed in the case of $T$. candida, which was sensitive at $\mathrm{pH} 5$, but not at $\mathrm{pH} 7$. On malt agar results for $U$. maydis and $S$. cerevisiae were the same as on the poorer agar medium of Coursen and Sisler.

Nekanil LN, even at $1000 \mu \mathrm{g} / \mathrm{ml}$, slightly retarded growth. Using mycelial disks instead of conidia as an inoculum slightly different values were obtained.

As measured by OD after $24 \mathrm{hr}$ the MIC values of tridemorph and Calixin for $U$. maydis and $S$. cerevisiae ( $\mathrm{pH} 7$ ) and for $T$.

TABLE I

Antifungal Activity of Tridemorph and Calixin at $\mathrm{pH} 7$ and $\mathrm{pH} 5$

\begin{tabular}{|c|c|c|c|c|c|c|}
\hline & \multicolumn{6}{|c|}{$\mathrm{MIC}(\mu \mathrm{g} / \mathrm{ml})$} \\
\hline & $\mathrm{pH}$ & U. maydis" & S. cerevisia" & T. candida" & B. allit" & C. cuctumerintm \\
\hline \multirow[t]{2}{*}{ Tridemorph } & 7 & 30 & 100 & $>1000$ & 10 & 30 \\
\hline & 5 & 100 & 100 & 100 & 30 & 100 \\
\hline \multirow[t]{2}{*}{ Calixin } & 7 & 30 & 30 & $>1000$ & 10 & 30 \\
\hline & 5 & 30 & 100 & 100 & 30 & 100 \\
\hline
\end{tabular}

\footnotetext{
"Coursen and Sisler agar; 4 days: $30^{\circ} \mathrm{C}$.

"Wickerham agar: 4 days; $30^{\circ} \mathrm{C}$.

Glucose agar: 7 days: $24^{\circ} \mathrm{C}$.
} 
candida $(\mathrm{pH} 5)$ were generally about three times lower in liquid medium than on agar medium. Also B. allii and C. cucumerinum were somewhat more sensitive in shake culture. In liquid mediuni Nekanil LN inhibited growth completely at the following concentration: $U$. maydis and $S$. cerevisiae $100 \mu \mathrm{g} / \mathrm{ml}, T$. candida (pH 5) $1000 \mu \mathrm{g} / \mathrm{ml}$, and $B$. allii and C. cucumerinum $>1000$ $\mu \mathrm{g} / \mathrm{ml}$. B. allii and C. cucumerinum were already slightly inhibited at 300 and 100 $\mu \mathrm{g} / \mathrm{ml}$, respectively.

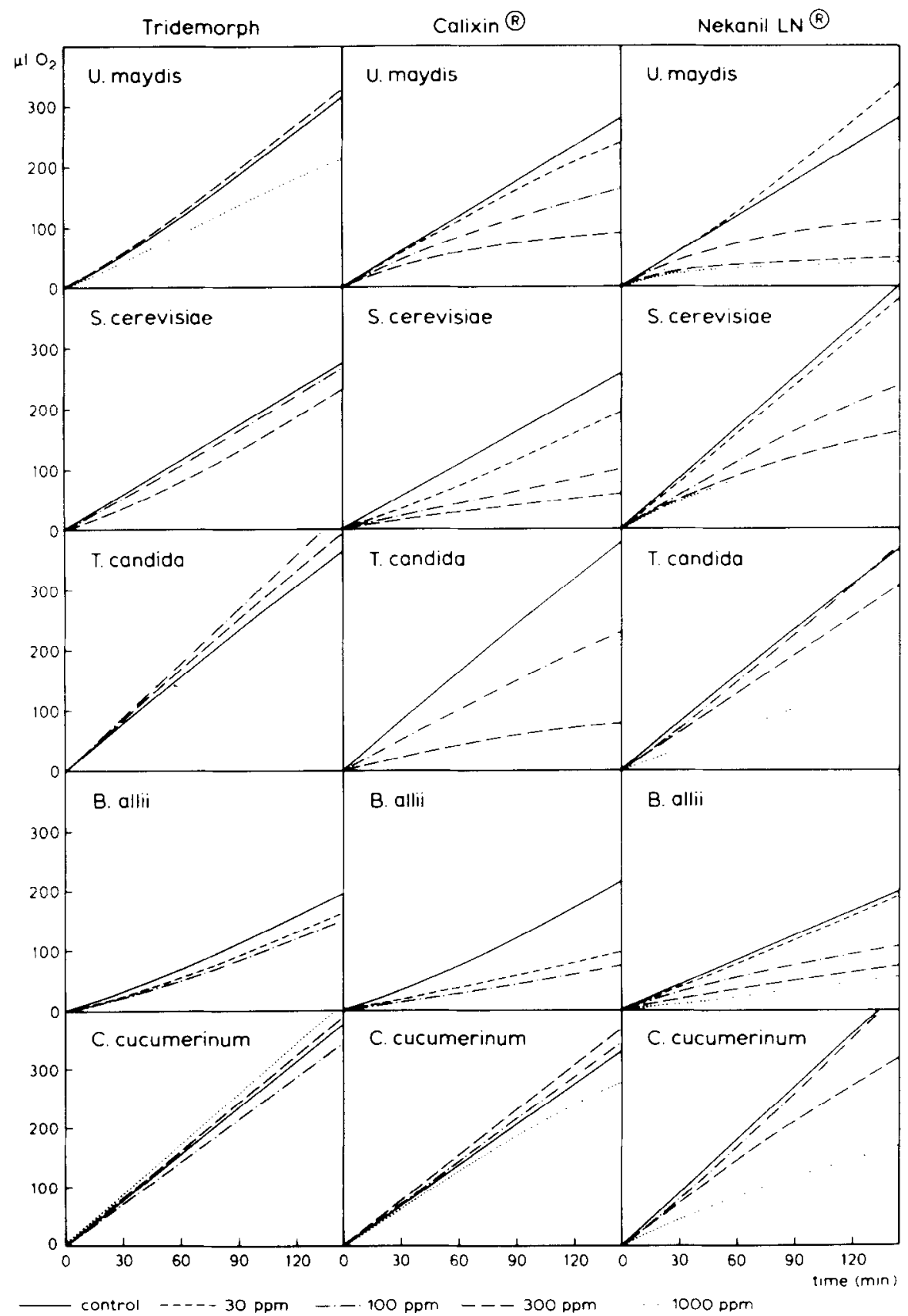

FIG. 1. Influence of tridemorph. Calixin, and $N$ ekanil $L N$ on respiration of $U$. mavdis, $S$. cerevisiat. B. allii, and C. cucumerinum in glucose phosphate buffer at $p H 7$ and $T$. candida at $p H 5$. 
Influence of Tridemorph, Calixin, and Nekanil LN on Respiration

Tridemorph, even at $300 \mu \mathrm{g} / \mathrm{ml}$, appeared unable to reduce the rate of glucose oxidation in $U$. maydis, $S$. cerevisiae, $T$. candida, and $C$. cucumerinum (Fig. 1): in the case of $B$. allii $100 \mu \mathrm{g} / \mathrm{ml}$ caused slight inhibition.

In contrast Calixin did inhibit glucose oxidation in these organisms (Fig. 1). This inhibition was, however, only observed at concentrations above the MIC values in liquid culture.

In contrast at concentrations equal to the MIC values in liquid cultures Nekanil LN inhibited glucose oxidation more or less strongly depending on the organism used (Fig. 1).

\section{Synergistic Influence of Tridemorph and}

Nekanil $L N$ on Respiration of $U$.

maydis, $S$. cerevisiae, and $T$. candida

Since the observed inhibition of respiration by Calixin could not be understood from the mere presence of its component Nekanil LN, the influence on oxygen consumption of a 3:1 mixture of tridemorph: Nekanil LN was studied and compared with the effect of these compounds separately (Fig. 2). This experiment revealed for all three organisms a very clear synergistic effect of tridemorph and Nekanil LN on respiration which largely explains the inhibition of oxygen consumption by Calixin.

\section{DISCUSSION}

Results showed that tridemorph even at high concentrations $(100,300$, or 1000 $\mu \mathrm{g} / \mathrm{ml}$ ) did not inhibit respiration of $U$. maydis, $S$. cerevisiae, $T$. candida, $B$. allii, and $C$. cucumerinum. Therefore, growth inhibition by tridemorph must be due to another mechanism. The report of Fisher (9) that tridemorph does not inhibit respiration in protoplasts of $B$. fabae and $N$. crassa is in agreement with these observations. In contrast we found that the formulated product Calixin did inhibit respiration. Thus one may postulate that Bergmann et al. $(3,4)$, Müller and Schewe $(5,6)$, and

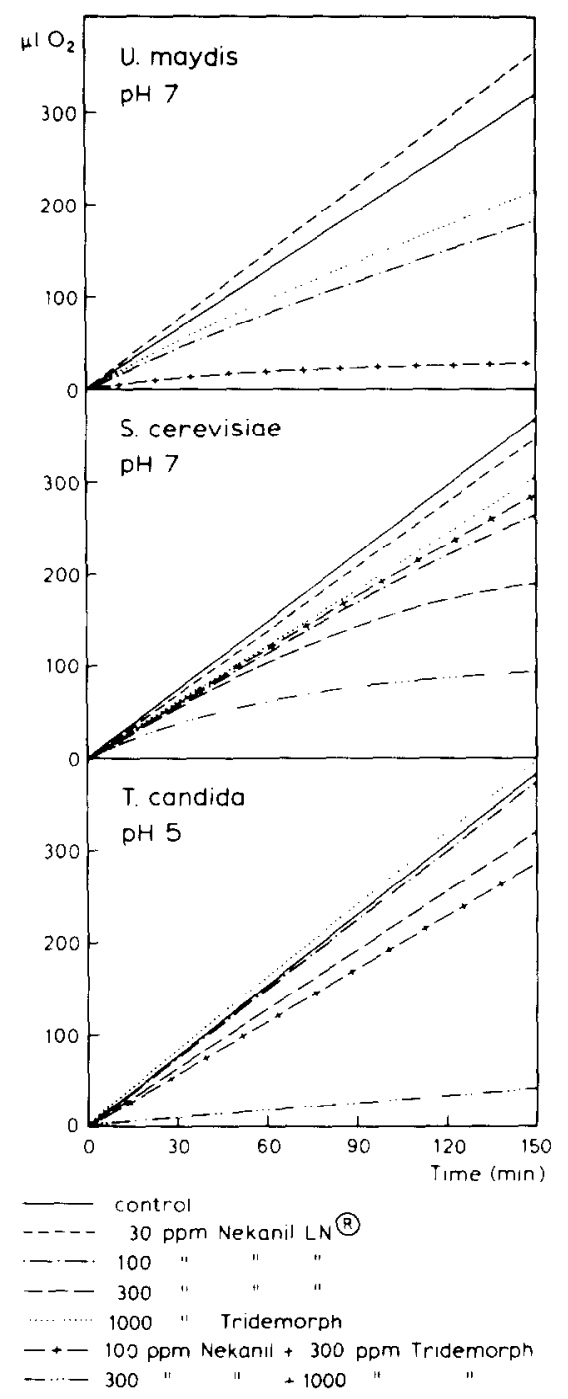

FIG. 2. Synergistic influence of tridemorph and Nekanil $L N$ on respiration of $U$. maydis and $S$. cerevisiat in glacose phosphate buffer at pH 7 and T. candida at pH 5 .

Rapoport (7), who reported inhibition of respiration of $T$. candida by tridemorph. used Calixin instead of pure tridemorph.

We also do not believe that inhibition of respiration can be the primary mode of action of Calixin because we found that growth inhibition of different organisms in liquid cultures already took place at concentrations which did not yet affect respiration. This respiration inhibition by Calixin cannot be due to the presence of 
tridemorph. However, the formulated product also contains Nekanil LN, a nonionic surfactant. Nekanil LN proved indeed to inhibit growth of various organisms, at least in liquid cultures, and inhibited respiration at the same concentration. Several other nonionic surfactants are also known to act on microorganisms $(15-18)$.

Further experiments showed a synergistic activity of tridemorph and Nekanil LN on respiration. We assume that this effect explains the unexpected inhibition of respiration by relatively low concentrations of Calixin.

The observation by Buchenauer (19) that Calixin far more than tridemorph caused an increase in conductivity in an experiment with leaf disks of bean plants points in the same direction.

We have now excluded inhibition of respiration as a possible mode of action of tridemorph. Further experiments, which will be the subject of a later publication, have revealed an interference of tridemorph with certain biosynthetic processes.

\section{ACKNOWLEDGMENTS}

The authors wish to thank BASF Aktiengesellschaft (Ludwigshafen. BRD) for financial support for part of these investigations and for a gift of tridemorph, Calixin, and Nekanil LN.

Also the skillful technical assistance of Mrs. A. J. M. Dekkers and Miss W. Oosterveld is gratefully acknowledged.

\section{REFERENCES}

1. E. H. Pommer und J. Kradel, Substituierte Dimethylmorpholinderivate als neue Fungizide zur Bekämpfung echter Mehltaupilze, Meded. Rijhsfac. Landbotwinetensch. Gent 32,735 (1969).

2. E. H. Pommer, S. Otto, and J. Kradel, Some results concerning the systemic action of tridemorph, Proc. Brit. Insectic. Fungic. Conf. 2, 247 (1969).

3. H. Bergmann. H. Lyr, E. Kluge, und G. Ritter, Untersuchungen zur Wirkungsweise von Tridemorph, in "Systemfungizide" (H. Lyr und C. Polter, Eds.), p. 183, Akademie-Verlag, Berlin. 1975.
4. H. Bergmann, The action of tridemorph on Torulopsis candida, Symposium on Systemic Fungicides (Abstract), Reinhardsbrunn, May 1977.

5. W. Müller und T. Schewe, Zur Wirkung von Tridemorph auf Elektronentransportpartikel aus Rinderherz-Mitochondrien, in "Systemfungizide" (H. Lyr und C. Polter, Eds.), p. 189, Akademie-Verlag. Berlin, 1975.

6. W. Müller und T. Schewe, Das Systemfungizid Tridemorph als Hemmstoff der Atmungskette voń Elektronentransportpartikeln aus Rinderherzmitochondrien, Acta Biol. Med. Ger. 35, 693 (1976).

7. S. M. Rapoport, Zur Wirkung des Calixins auf Elektroentransportpartikel aus RinderherzMitochondrien, Symposium on Systemic Fungicides (Abstract), Reinhardsbrunn, May 1974.

8. D. K. Garg and R. S. Mehrotra, Effect of some fungicides on growth, respiration and enzyme activity of Fusarium solani f.sp.pisi, Z. Pflananschut: 10, 570 (1975).

9. D. J. Fisher, A note on the mode of action of the systemic fungicide tridemorph, Pestic. $S$ ci. 5, 219 (1974).

10. A. Kaars Sijpesteijn, in "Systemic Fungicides" (R. W. Marsh, Ed.), 2nd ed., p. 153, Longman, London. 1972.

11. C. Polter and G. Casperson. The influence of tridemorph on the lipid composition and the uitrastructure of Botrytis cinerea. Symposium on Systemic Fungicides (Abstract). Reinhardsbrunn. May 1977.

12. B. W. Coursen and H. D. Sisler, Effect of the antibiotic, cycloheximide, on the metabolism and growth of Saccharomyces pastorianas, Amer. I. Bot. 47, $541(1960)$.

13. H. Roman. A system selective for mutations affecting the synthesis of adenine in yeast, $C$. Tral. Lah. Carlsherg 26, 299 (1956).

14. A. Kaars Sijpestcijn, M. J. Janssen, and G. J. M. van der Kerk, Investigations on organic fungicides. XI. The role of metals and chelating agents in the fungitoxic action of sodium dimethyldithiocarbamate (NaDDC). Biochim. Biophys. Acta 23, 550 (1957).

15. J. Kranz, Über die Wirkung einiger Emulgatoren auf die Konidienbildung von Mycosphaerella musicola Leach, Z. Pflana'nhr. Pflanz'nsclutt 71, 405. (1964).

16. E. Prohaska and R. Brunner, Uber die resistenzvermindernde Wirkung oberflächenaktiver Stoffe, insbesonders von Netzmitteln bei penicillinresistenten Staphylokokken, $Z^{\prime} n$ tralbl. Bakteriol. Parasitenk. Infehtionskr. Hyg. Abt. I Orig. 176, 455 (1959).

17. A. Lamikaura and M. C. Allwood, The antibacterial activity of nonionic surface-active agents, Microbios Lett, 1, 97 (1976). 
8. E. C. Hislop, D. R. Clifford, M. E. Holgate, and P. Gendle. Eradication of apple powdery mildew (Podosphaera leucotricha) with dormant season sprays of surface-active agents, Pestic. Sci. 9, $12(1978$.
19. H. Buchenauer, Various response of cell membranes of plant and fungal cells to different systemic fungicides, Proc, Int. Plant Prot. Congr. Moscou 3, 94 (1975). 